\title{
ENTRE $O$ HUMANO E O FERINO NOS ESPAÇOS DE EXCEÇÃO: A PASSAGEM DOS INOCENTES, DE DALCÍDIO JURANDIR ${ }^{1}$
}

\section{BETWEEN THE HUMAN AND THE HONEY IN EXCEPTION SPACES: THE PASSAGE OF THE INNOCENTS, OF DALCÍDIO JURANDIR.}

Viviane Dantas Moraes ${ }^{2}$

\begin{abstract}
RESUMO: O romance Passagem dos Inocentes, do paraense Dalcídio Jurandir, é uma narrativa sobre o caos social urbano e sobre as dificuldades da vida na periferia de uma cidade após a falência de um projeto econômico, o pós-ciclo da Borracha na Amazônia. Um dos principais objetivos do projeto literário de Dalcídio Jurandir é desmistificar a Amazônia retratada nas crônicas dos viajantes europeus, ao vislumbrar uma crítica social e um estado de calamidade humana, política e social que se divide entre os espaços urbano e ribeirinho. Nesse sentido, a narrativa dalcidiana expóe a regiâo amazônica como um frequente espaço de violaçăo de direitos e de violência à vida, configurando um estado de exceçăo invisível na contemporaneidade. $\mathrm{O}$ artigo propóe um estudo que entrelaça literatura, filosofia e direito, tópicos relacionados às teorias do estado de exceçăo, poder soberano e vida nua, do filósofo italiano Giorgio Agamben.
\end{abstract}

Palavras-chave: Amazônia; espaço de exceçâo; violência; direito.

ABSTRACT: The novel Passage of the Innocents by Dalcídio Jurandir is a narrative about the urban chaos, about the difficulties of life in the periphery of a city after the bankruptcy of an economic project. One of the main objectives of the literary project of Dalcídio Jurandir is to demystify the Amazon portrayed in the chronicles of the European travelers, when glimpsing a social critique and a state of human, political and social calamity that divides between urban and riverside spaces. In this sense, the Dalcídio's narrative exposes the Amazon as a frequent space of violation of rights and violence to life, configuring an invisible state of exception in contemporaneity. The article proposes a study that interweaves literature, philosophy and law, related to the theories of the state of exception, sovereign power and naked life, of the Italian philosopher Giorgio Agamben.

Keywords: Amazon; space of exception; violence; right.

1 Este artigo é fruto de parte das pesquisas de minha tese de Doutorado intitulada A vida nua em Dalcídio Jurandir: metamorfoses do estado de exceçâo (2017) - Universidade Federal do Pará.

2 Professora adjunta de Língua e Literatura francesa e francófona do curso de Letras na Universidade Federal do Maranhăo (UFMA). E-mail: viviane.danttas@gmail.com 
A Amazônia literária do escritor Dalcídio Jurandir (1919-1976) é uma antimusa de contrastes e contrapontos à narrativa hegemônica movida pelos vislumbres dos cronistas viajantes europeus do século XVI. O escritor paraense, nascido na cidade de Ponta de Pedras, situada no arquipélago do Marajó, traz no conjunto de sua obra intitulada Ciclo do Extremo Norte, o incômodo contraditório, o desvelador e crítico olhar acerca das mazelas sociais, das precariedades de pensamento político, das ausências de lei e de justiça, de uma faceta da vida amazônica desconhecida porque ignorada. Essas questôes nos sâo descortinadas por um narrador em terceira pessoa que, por meio de Alfredo, protagonista dos dez romances que compóem o Ciclo, desfolham-se personagens e situaçóes que se encontram no entremeio do humano e do ferino, da sanidade e da loucura, da ruína e da imaginaçáo.

Em uma escrita que se constrói numa atmosfera sublime aterradora, Dalcídio Jurandir nos oferece um cenário inquietante de uma Amazônia em sofrimento humano, entre a solidăo e o isolamento social, com o objetivo de demonstrar os problemas íntimos que assolam uma sociedade olvidada pelo Estado em suas necessidades e direitos mais básicos. Ressalta-se, no entanto, que a narrativa dalcidiana é imbuída de memória, de história e de cultura e, podemos, nesse sentido, inferir a esse aspecto uma relaçáo com a ideia de "documento de cultura, documento de Barbárie", do filósofo alemâo Walter Benjamin. A técnica de escritura do autor nos permite perceber que há uma melancolia pela destruiçâo da cultura no rememorar dos personagens a cada livro, e a cada novo acontecimento e desilusáo, um temor pelo futuro. Sobre um dos aspectos do conjunto de sua obra, Dalcídio confessa, esclarecendo que sua visăo como romancista é de que a realidade social é feita de lutas:

\footnotetext{
Os meus livros ficariam como instrumento de nostalgia, o registro de uma cultura que está sendo destruída pela invasăo da Amazônia. Uma espécie de destruiçáo sistemática dos costumes, sem fixar o progresso, sem dar benefícios às populaçôes. O quadro cultural está mudando. Mas o quadro de exploraçăo e de pobreza persiste. A situaçấo social e humana vai para pior. Existe o progresso técnico, mas para destruir, para manter a exploraçâo (FOLHA DO NORTE, 1976)3.
}

Os espaços de narrativa em suas obras se movimentam de maneira diversificada e simbólica, entre a Amazônia ribeirinha, aquela do caboclo das ilhas, como denomina Dalcídio, e também a Amazônia urbana, representada pela capital Belém do Pará. Espaços esses que nos servem de parâmetro e que demarcam a travessia para as descobertas de Alfredo em dois universos diferentes com problemas em comum. O preâmbulo exposto até aqui se faz necessário para a análise do romance proposto, visto que este nâo se encontra desatrelado da concepçăo do projeto estético do autor que envolve toda uma ideologia de problematizar os vários espaços amazônicos até entâo desconhecidos. Passagem dos Inocentes (1963), o romance, se passa no subúrbio da capital Belém, em uma Amazônia citadina e renegada de um imaginário cultural homogêneo em relaçăo à regiăo.

Portanto, na perspectiva de diálogo entre literatura e filosofia é que se baseia esse estudo. Mais precisamente baseando-se nos questionamentos sobre o parâmetro

3 Trecho de entrevista concedida ao escritor paraense Haroldo Maranhăo, para o Jornal Folha do Norte, em 1976. 
contemporâneo de estado de exceçâo a partir de estudos do filósofo italiano Giorgio Agamben. As novas reflexóes sobre o conceito, advindas das experiências de catástrofes humanas do século XX, conduzem à observaçâo e à problematizaçăo das práticas no exercício do direito no Ocidente.

O romance Passagem dos Inocentes (1963), o quinto livro do Ciclo do Extremo Norte, traz na paisagem urbana amazônica, representada pela capital Belém, no Pará, um contexto que podemos considerar como sendo de calamidade pública, pois, na obra, há uma situaçấo extrema ligada ao episódio das mortes em massa das crianças na Santa Casa de Misericórdia, maternidade pública estadual. A narrativa consolida-se mediante o olhar cada vez mais desencantado do personagem Alfredo, uma das propostas de Dalcídio Jurandir relacionada ao seu projeto estético, que é o de escancarar as mazelas sociais e desconstruir a ideia de que o progresso e a civilizaçăo estăo ligados à promessa de felicidade.

Após a fracassada experiência de Alfredo na casa dos Alcântara, como pudemos observar na análise do romance Belém do Grāo-Pará (1960), o início de Passagem dos Inocentes descreve a sua volta desolada para a Ilha do Marajó. A açăo se passa em Muaná, uma das cidades do arquipélago. Lá, o menino conhece o avô, seu Bibiano, pai de D. Amélia, um velho senhor que tira parte de seu sustento tecendo cestos e paneiros. A ida para Muaná, depois do desastroso desabamento da casa onde vivia como agregado em Belém levava-o ao reencontro da vida amazônica ribeirinha, à lembrança da irmá Mariinha, vítima da malária, da menina Andreza, a qual năo se sabia o paradeiro, e ao conhecimento das origens da măe, as dificuldades, a moradia precária, a resignaçáo de que aquela situaçăo tinha a ver com sua cor, pois D. Amélia era preta. A mulher mostrava para o filho onde eles passaram os primeiros dias após o seu nascimento. Era a barraquinha do avô:

A casa de portais escuros, sem reboco, um pouco pensa, como se o telhado pendesse para um lado e o corpo da casa para o outro. A sala de puro aterro, umas cruas tábuas soltas no quarto que fedia a unguentos e a cera de santo; ao pé do jirau, um tristinho fogăo com um peixe sabrecado na trempe fria. Fora, o pilăo emborcado, a panela de planta pendurado no esteio, os verdoengos feixes de varas, e da mulher a cara tăo amarela mas, meu Deus, por que tăo amarelona? Alfredo queria ouvir ali o seu primeiro choro. Aquela mulher, rosto de manga descascada, tinha escutado, tinha? [...] O cheirume aumentava. A mulher, conversando com a măe, exalava sobre as coisas o amarelo de seu rosto cor de palha [...] (JURANDIR, 1984, p. 16).

A palhoça de seu Bibiano aparece como uma, dentre muitas no Marajó, em tais condiçôes precárias de estrutura e de higiene. A mulher amarelona da cena acima que impressionou Alfredo transparecia a imagem da fome, conforme outras evidências do uso da cor amarela referente a isso. O menino Antônio, do Tocantins, do romance Belém do Grâo-Pará, por exemplo, era descrito como amarelo de fome. A cena narrada acima nos remete a um texto de Dalcídio Jurandir, publicado no jornal Folha do Norte, chamado "Remédios amargos, mas necessários" (1950). O autor tece um panorama da vida amazônica e a agonia de uma mulher perante a morte: 
Palhoça clássica, girau imundo, o quarto escuro e a indigência completa. A velha estava desenganada. Era uma dor. Conheço bem essa dor que fustiga os ventres, o peito, as cabeças do povo. Dor. 0 dr. Catete examinou a mulher que parecia um bicho, abandonada que era um trapo. Disse-me, ao sair: - É fome [...] no outro extremo da vila, tinha um cadáver no girau. Tinha morrido de fome. E de boubas. Năo havia dinheiro para fazer caixăo. Numa palhoça ao fundo da vila, criancinhas com fome, a mulher esquelética e, cobrindo o quadro, o paludismo (FOLHA DO NORTE, 1950).

Năo fosse uma matéria jornalística, o texto muito se assemelha à narrativa literária dalcidiana em seu grau de realismo e denúncia. De acordo com o que foi muitas vezes referendado, o drama social ligado à fome é uma das questóes sempre presentes na obra do escritor. A mulher da matéria é a vida nua, feito bicho, abandonada e literalmente morta de fome.

No romance Passagem dos Inocentes, temos inicialmente as cenas do reencontro de Alfredo com a vida marajoara, algumas rememoraçôes e o encontro com parentes. Apesar de tudo, ele quer voltar para Belém em busca de uma nova chance. É quando se deparam, ele e a máe, com dona Cecé, sobrinha de Major Alberto, que oferece abrigo para o menino em sua casa na capital. Alfredo, entăo, se encaminha de volta para Belém, onde se passa a segunda parte da narrativa. Ele vai acompanhado de um conhecido, o Leônidas, no entanto, o retorno era "agora, em uma curiosidade triste" (JURANDIR, 1984, p. 67).

A vida nua e o estado de exceçáo, no romance em questăo, sâo elementos de análise na narrativa que abrem as frestas para a presença da resistência, como veremos posteriormente. Tratamos aqui da relaçáo entre literatura e resistência inspirada pelo pensamento do crítico literário Alfredo Bosi a partir de seu ensaio "Narrativa e resistência", que abriu caminho para muitas interpretaçôes sobre o pensar que "resistência é um conceito originalmente ético e nâo estético" (BOSI, 2002, p.11). Nesse sentido, um apontamento importante no que tange a relaçăo existente entre resistência e exceçáo é a de Elcio Cornelsen:

Em geral, há uma gama de sentidos atribuídos ao conceito de "resistência", seja como resistência política, social, cultural e literária. Em sua maioria, esses sentidos sáo empregados para se refletir sobre posturas e práticas de resistência a regimes de exceçăo (CORNELSEN, 2014, p. 96).

Interessante notar que todos os elementos e possibilidades de se pensar a resistência citados por Cornelsen fazem parte da construçăo do discurso literário de Dalcídio Jurandir e perpassam seu projeto estético, que năo deixa de ser movido por uma ética. Ao longo do que já foi apresentado e analisado sobre a produçáo do autor, nota-se a sua preocupaçăo com as questóes políticas, sociais, culturais e literárias. Podemos considerar, portanto, que o conjunto da obra de Dalcídio dialoga com a resistência, e mesmo que nâo contextualize regimes de exceçăo, constrói espaços de violaçâo e situaçôes de vida nua e, consequentemente, de exceçăo.

Na narrativa, temos um contexto que se caracteriza como uma situaçâo de emergência: a cidade de Belém está escancarada ao descaso do governo, à miséria, a um surto avassalador de disenteria bacilar responsável pela morte irrefreável de crianças, acúmulo de lixo pelas ruas, infestaçấo de moscas por todos os cantos, parte da populaçáo 
vivendo literalmente na lama, insatisfaçăo do trabalhador com péssimas condiçóes de trabalho e atrasos de salários. Tal contexto de calamidade só poderia culminar para um resultado: a revolta popular e os protestos. Nesse sentido, a obra aglomera vários elementos da construçấo da narrativa literária e sua relaçăo com a resistência que, de acordo com Bosi:

É um movimento interno ao foco narrativo, uma luz que ilumina o nó inextricável que ata o sujeito ao seu contexto existencial e histórico. Momento negativo de um processo dialético no qual o sujeito, em vez de reproduzir mecanicamente o esquema das interaçōes onde se insere, dá um salto para uma posiçăo de distância e, deste ângulo, se vê a si mesmo e reconhece e póe em crise os laços apertados que o prendem à teia das instituiçôes (BOSI, 2002, p. 134).

Esse sujeito do qual fala Bosi podemos enxergar na figura de Alfredo, pois é pelo olhar do garoto e nas suas interaçóes com o mundo ao seu redor, a partir de questionamentos e parâmetros entre Belém e a vila de Cachoeira, que percebemos o estremecer dos laços e o despertar para o sentimento de injustiça. Essa relaçăo pode ser observada de forma gradual nos romances de Dalcídio Jurandir e que parece desabrochar em Passagem dos Inocentes, com a tomada de consciência do menino ao se deparar com as manifestaçōes de rua. Algumas cenas da obra serâo analisadas.

O título da obra, devido a duas situaçōes que aparecem no romance, nos oferece um duplo sentido. O primeiro se refere ao nome da rua em que mora D. Cecé, na periferia, lugar onde Alfredo se instala. O segundo faz alusăo à morte das crianças, dos recém-nascidos que, em alguns momentos da narrativa, eram chamados de "inocentes". As duas possibilidades convergem para a mesma condiçâo de violaçăo, de esvaziamento de direitos, de abandono, de vida nua e exceçăo.

A Passagem dos Inocentes, a rua, era um local encharcado pela lama. D. Cecé tinha vergonha de dizer que morava em uma rua precária de condiçôes de habitaçâo e higiene, sendo o reflexo de um total descaso. Por isso, ninguém no Marajó sabia da verdade. Mas a chegada de Alfredo, desde seu trajeto à casa da prima, acompanhado do irmáo dela, o Leônidas, foi um desvelamento da triste realidade que o aguardava.

\begin{abstract}
Ao cruzarem a entrada, a vala se escancarou, uma goela que podia levar os dois pelos porōes da terra, até lá em baixo, nas casas sepultadas. Casas? Ali na boca se via um palhame grosso, arrepiado, encharcado. [...] encafuado em si mesmo, sob o chuvisco, Alfredo mal andava, se abanando. Entrava-se pela Curuçá [rua], passava-se por ali, saía-se onde? À (sic) noite, muito baixa, espremia no escuro o palhoçal, comia aquela populaçấo ali entocada como um sapo. Uma e outra míngua de claridade por baixo das portas, das frestas, fugiu pelos buracos da parede. E se dali voltasse, corresse a se agasalhar na Rui Barbosa nem que fosse pra dormir no cimento da sala, ao pé da porta, a cabeça em cima do cano d'água? E aqui o poste, cadê luz? Dali em diante, sem nenhum clarume, que-que era que náo se enxergava? Onde? Porta de inferno, te abre, te apresenta, casa do săo nunca (JURANDIR, 1984, p. 80-81).
\end{abstract}

Observa-se que a caminhada dos personagens pela rua é a mais penosa possível. A lama, protagonista da Passagem, é o elemento que caracteriza uma condiçăo sub-humana de grotesco e abjeto. É interessante notar a descriçâo da localizaçáo das moradias 
como "casas sepultadas", o que faz referência à morte, à decomposiçăo de corpos, mas, nesse caso, de seres vivos, que sâo, porém, matáveis, esquecidos, jogados literalmente à margem dos direitos fundamentais. Nota-se que Alfredo, em meio à agonia, elucubra, em pensamento, se refugiar na antiga casa dos Alcântara - do romance "Belém do Grâo-Pará" -: "dormir no cimento da sala, ao pé da porta, a cabeça em cima do cano d'água?" (DALCÍDIO, 1984, p. 81), ou seja, em condiçôes tăo pouco favoráveis ou que lhe devolveriam a dignidade. O lugar, desde o primeiro contato considerado pelo menino como um inferno, era uma escuridăo só, e como ele mesmo percebe, existe a ausência de iluminaçâo pública na Passagem.

Algumas características da Passagem dos Inocentes mencionadas na citaçâo anterior nos demonstram o porquê daquele lugar ser conhecido como "Covóes", como Alfredo reconheceu: "O pé pesava, o sapato uma bolsa de lama, e lama lhe escorria dentro do peito. De repente, a palavra para aquilo tudo: Covôes. Covôes. O juízo lhe diz: Covôes. COVÓES COVÔES" (JURANDIR, 1984, p. 82). Percebe-se, no personagem, um misto de desgosto com uma profunda vergonha, que se converte em lama dentro do peito e nos sapatos, um ícone da dignidade, como já foi discutido anteriormente.

A repetiçăo da palavra Covóes em sua mente, que se gradua de acordo com seu desespero, expresso na diferença da linguagem da escrita minúscula e maiúscula, se deve ao fato pelo qual o menino rememora já haver escutado a madrinha-mâe, D. Inácia Alcântara - do romance "Belém do Grăo-Pará" -, em uma de suas nervosas conversas com a filha, falar sobre a Passagem: "Năo sei se a Deus ou se ao Diabo deves agradecer, desgraçada, estar morando aqui na Gentil [Avenida] e năo lá nos Covóes dentro da bosta (JURANDIR, 1984, p.82). A declaraçâo da mulher, ao comparar a lama à bosta, vaticina o despojo da populaçáo daquele lugar e a submissăo à condiçăo no entremeio do humano e do animal, remetendo ao grotesco e aos primórdios da origem do conceito, que nas misturas do humano e do animal, eram imagens disformes, indecifráveis que, espelhadas nos moradores da Passagem dos Inocentes, tornavam-se uma sociedade inexistente enquanto vida cidadă, mas presente enquanto vida nua. $O$ grupo de pessoas que está a esmo em moradias questionáveis do ponto de vista das condiçôes dignas na tal passagem, alude à ideia de bando, dos abandonados pela lei, expressăo usada por Agamben para caracterizar tais grupos, situaçōes, espaços.

Segundo o filósofo italiano, o estado de exceçăo está intimamente ligado à vida, antes de ser ligado ao direito. Na verdade, trata-se de uma condiçăo de ausência e suspensâo dos direitos fundamentais do homem, sobretudo do seu direito à vida, assim como da suspensấo da ordem jurídica. A fim de caracterizar os espaços criados pelo estado de exceçăo, Agamben utiliza os conceitos de zona de indistinçăo e vida nua. Para explicar o primeiro, Agamben (2010) utiliza a metáfora do lobisomem e do bando, para afirmar que em um espaço vazio de direitos, de leis e de normas, o ser humano se torna matável, por ser visto em seu estado de natureza, ou seja, há uma vida nesse náo-lugar que é "indigna de ser vivida"; portanto, se năo há amparo jurídico, a vida se torna vulnerável a qualquer ameaça. A vida nua, nesse contexto, vem a ser o despojamento do caráter humano dessa vida, o demasiado humano revelado na esfera da desumanizaçăo. Deste modo, esse homem, o Homo Sacer, como Agamben o denomina, se encontra no limiar entre os homens e feras, na indistinçăo entre o humano e o ferino: “ 
a transformaçăo em lobisomem corresponde perfeitamente ao estado de exceçăo, por toda a duraçáo do qual (necessariamente limitada) a cidade se dissolve e os homens entram em uma zona de indistinçăo com as feras" (AGAMBEN, 2010, p.107).

O bando, o grupo em que perambulam esses seres disformes, representa a figura do abandono à própria sorte, o bando materializa a violência do poder soberano em sua essência paradoxal visto que ao mesmo tempo em que impóe a violência pelo direito, conserva-a sob o mesmo pressuposto. Segundo Agamben (2010), o que foi posto em bando é remetido à própria separaçăo e, juntamente, entregue à mercê de quem o abandona, ao mesmo tempo excluso e incluso, dispensado e, simultaneamente, capturado (AGAMBEN, 2010, p. 109).

Nesse sentido, na pólis, no ambiente citadino, o protagonista Alfredo começa a se incluir nesse espaço do bando, dos abandonados pela lei, desde o romance anterior, Belém do Grăo-Pará. Se o intuito do menino em Belém era estudar, o cenário que se abria para ele parecia traçar o mesmo caminho da derrocada da casa dos Alcântara, mas, dessa vez, ele foi direto para a periferia, ou seja, as dificuldades se mostravam piores, inviáveis, desanimadoras:

Leônidas quis pegá-lo pela măo, guia-lo, ele se arredou, rejeitou o amparo, metendo entăo bem fundo o pé, sapato e meia, no lamaçal. Arrancou a perna como se a trouxesse podre, esmagada, cheia de bicho. [...] gaguejou nomes, batia o sapato... Leônidas o segura. Fugiu deste, a lama na perna, os bichos lhe subindo, mandava a D. Celeste, a casa dela, o estudo, a cidade para as profundas. Miaus dos gatos sucediam-se como uma vaia em meio aos carapanás, estes agora menos (JURANDIR, 1984, p. 81).

As dificuldades de imersâo na vida citadina para quem năo tem recursos arrastam as pessoas para o caos urbano, para a vida desordenada, para os náo-lugares do ordenamento jurídico. Nesse sentido, criam-se espaços esvaziados de direito porque sáo irreconhecíveis legalmente, tornando-se, assim, antros de sobrevivência. O sentir-se nu e despojado náo impulsiona ao vislumbre de futuro e, no caso de Alfredo, tem a ver com o processo educacional que sempre é ameaçado pelo constante assombro da exceçâo. Podemos comparar a passagem dos Inocentes, a rua, ao que a escritora Carolina Maria de Jesus denominou para as favelas de "quarto de despejo de uma cidade", no seu livro Quarto de despejo (1960), que relata o diário de uma favelada. O que se despeja em uma favela, ou em algum lugar que se assemelhe a ela na sua condiçăo de desordem, sâo os considerados dejetos da sociedade, os que enfeiam e enlameiam a visăo da cidade, gerando espaços de violaçăo, de violência, de fome, de falta de água, de falta de higiene e de esperança.

Durante seus primeiros dias após o retorno e em uma de suas voltas da escola, Alfredo nota, com curiosidade, um homem macambúzio a quem ele se refere como "espantalho". É um personagem citado poucas vezes no romance, mas que nos oferece uma possibilidade de análise interessante. O homem-espantalho era o homem-múmia, o vivo-morto da Passagem. A partir dos pensamentos de Alfredo, podemos apontar que o tal espantalho seria um representante de Eutanázio na Passagem:

Chegava Alfredo no mesmo espanto e indagaçấo: quem deve ser aquele, sempre ali na janela da casa velha do canto, o espantalho? [...] assim de passagem, era uma 
suada inchaçăo a figura, e logo, podendo ver bem, algo mais que suor e inchaço e que interditava a casa velha, proibindo alguém de entrar. Só ele ali? Nâo, que rumor de gente pelos fundos se escutava. Náo nascia da carne do rosto a modo morta nem do nariz, beiço ou da testa sobre as pálpebras fundas, o desconforme, o ar padecente. Vinha de dentro da figura exposta ao sol da manhă. Daquele silêncio e imobilidade dele na janela uma solidáo escorria. Às vezes, sem camisa, às vezes dobrado no peitoril, espreitava a rua, atrás do que náo tem nem nunca viu no mundo, e ali desterrado, ali maldito e sempre, até que o pardieiro fosse chăo adentro na goela de fumo, enxofre e fogo (JURANDIR, 1984, p. 122-123).

Percebemos na figura do personagem uma apatia, uma imobilidade perante aquela situaçáo caótica. Um homem na janela, inerte, silenciado a observar o universo preto-claro beckettiano e homens disformes e deformados a perambular pelo lamaçal, enquanto se curva resignado "atrás do que năo tem nem nunca viu no mundo". O espantalho, que causava espanto e curiosidade em Alfredo, nos relembra em alguns aspectos, assim como Eutanázio, o protagonista do primeiro romance Chove nos Campos de Cachoeira (1941), alguém anônimo, exposto à morte, ao padecimento. $O$ espantalho é o a expressăo disforme do Homo Sacer perante a condenaçấo certa àquela realidade.

O espantalho aparece em mais um momento importante da narrativa: no jogo de futebol. Teceremos consideraçóes acerca da existência de uma partida de futebol em uma obra dalcidiana que, até esse romance do Ciclo do Extremo Norte, ainda nâo havia ganhado um espaço significativo na narrativa. Próximo à passagem dos inocentes havia um campinho de futebol, se é que se podia chamá-lo assim, na sua decadente estrutura, com uma mangueira no meio e as casas ao redor, onde havia "as duas traves, sem uma cal, coitadas. Também em volta chegavam as senhoras moscas..." (JURANDIR, 1984, p. 225).

A atmosfera que pairava no jogo era fúnebre. A morbidez era pelas mortes das crianças na Santa Casa de Misericórdia e pela infestaçâo de moscas na Passagem. Como declarou um dos personagens, "joga-se bola no meio da morte e do mosqueiro. Estamos no apocalipse" (JURANDIR, 1984, p. 224).

Percebe-se que o futebol para os 22 meninos que brincavam na Passagem era uma distraçấo, um consolo em meio ao caos e, porque năo dizer, uma forma de resistência em se mostrar vivos, despertos e driblando a morte em meio à opressâo. $O$ autor nos oferece nessa cena, que toma um pequeno capítulo da narrativa, um quadro cultural comum nas periferias das grandes cidades, onde o futebol aparece enquanto manifestaçăo da cultura brasileira. Em meio a tanta tristeza e desolaçăo, algumas pessoas da Passagem se perguntavam, criticando, se aquela partida seria viável naquele momento em que tudo desmoronava. No entanto, o futebol surge mesmo na lama, ultrapassando as estruturas desconformes, como uma tentativa de protesto, de năo resignaçáo. Seu Aniceto é contra a partida nesse local, mas Alfredo argumenta:

O velho alegava que o largo teve mastro de santo, foi terreiro de boi-bumbá, velório do Sandoval, de bichos. [...] agora era só bola, bola, bola, a invençăo da bola no meio das casas, só restava era a competência dos que consideravam apropriado o terreno para um divertimento daquele, tăo bruto, que o inglês trouxe, além do mais a mangueira no meio. 
- Mas é um adiantamento mesmo, mestre Aniceto, é o progresso, rebatia o baixotote, de pijama sem alamares (JURANDIR, 1984, p. 226).

Mestre Aniceto continua o falatório, inconformado. Para ele, a resoluçăo dos problemas sociais era mais urgente:

Vâo cuidar do lixo, queimar os doutores no forno da Cremaçăo, soprar essa moscarada, que a cidade está que nem curtume. É ou năo é um castigo? Ademais năo tem licença na Fiscalizaçăo. Passa o fiscal, lá vai multa, desfinca as traves, o mastro pro fogo (JURANDIR, 1984, p. 228)

Alfredo, ao se deparar com as palavras "licença" e "fiscalizaçăo", contesta mestre Aniceto e demonstra ter conhecimento da lei e questiona com um ar de deboche: "-Mas legalmente a Passagem dos Inocentes existe? Existe? Existe? Categoria de rua, adeus que tem. Existe?" (JURANDIR, 1984, p. 226).

A partir do diálogo entre os personagens Alfredo e mestre Aniceto, citados anteriormente, podemos extrair alguns pontos interessantes. $O$ menino alega que o futebol é um símbolo de progresso naquela realidade flagelada. O significado de progresso, nesse contexto, aparece com um sentido construtivo de algo valoroso. E naquele espaço que antes era lugar de mastro de santo, continuaria a ser, de certo modo, um território sagrado para aqueles meninos que viam na partida de futebol uma forma de resistir às mazelas sociais.

Nesse ínterim, a informaçăo sobre a legalidade da Passagem dos Inocentes e a insistência irônica de Alfredo ao perguntar, várias vezes, se ela "existe?", convém com o que discutimos até o momento, pois, em sua contestaçáo, o menino, de alguma forma, questiona a existência da lei e reconhece a inexistência daquela rua e de seus moradores perante a justiça. Ou seja, Alfredo desperta para a consciência do esvaziamento jurídico, ao supor que a rua é um năo-lugar, um antro de abandono e esquecimento. Portanto, a partida de futebol, que poderia apenas ser considerada uma simples brincadeira, culminou por expor várias problemáticas, além de desvendar várias outras.

As várias outras questōes desvendadas dizem respeito ao protagonismo que a bola adquire na cena do acontecimento da partida. A ânsia de se correr atrás dela - que invadia as casas, derrubava os varais, despertava a raiva das donas de casa -, descobria o que os moradores escondiam nos barracos, ou seja, expunha a intimidade da Passagem. A bola, sob o olhar de Alfredo, parecia ser um objeto inanimado assim como o seu caroço de tucumá:

Esta, pensou Alfredo, era o seu carocinho de tucumá subindo e descendo, retirando dos jogadores e da assistência, como uma fita mágica, os desejos e os sonhos impossíveis da Passagem. [...] a bola volteava sua fita imensa, invisível, que Alfredo recolhia em seu desassossego; aquelas criaturas seguindo a bola, que sonhavam, que desejavam, que pediam? (JURANDIR, 1984, p. 228).

O jogo de futebol da Passagem, no contexto de crise em que se encontrava a cidade por causa das mortes dos bebês, parecia profanar o momento que pedia luto. A bola, no entanto, significava uma persistência daqueles garotos em busca de algum sentido 
para sobreviver: "Atrás dela a obstinaçăo, a astúcia, a esperança, a sede de algo que a bola escondia das duas equipes e da populaçăo" (JURANDIR, 1984, p. 230). Portanto, em um espaço de exceçáo e de vida nua, o futebol torna-se uma das manifestaçóes da resistência.

Conforme mencionado desde o início, a segunda parte da narrativa do romance em questâo se passa em Belém, no momento em que um surto de disenteria bacilar assola a cidade e incontáveis bebês morrem na maternidade. Alfredo ainda tentava compreender aquele cenário:

Mas pensou ser o trivial em Belém no que tocava à mortandade de crianças. Năo era assim em Cachoeira? A lei năo entrou no chalé e năo tirou de lá a Mariinha? [...] ao mesmo tempo, outra nota oficial declarou que ocorreu em Belém um surto de disenteria bacilar com alta letalidade, atacando, de preferência, infantes e crianças, subnutridas e desidratadas nos bairros pobres, onde as condiçóes e hábitos de higiene săo precários e a educaçấo sanitária é desconhecida... (JURANDIR, 1984, p. 176).

Observa-se que a surpresa de Alfredo e o seu questionamento demonstram o quanto a morte, mesmo em demasia, já fazia parte do cotidiano do garoto e já havia se naturalizado. O despertar de Alfredo para a movimentaçáo popular em prol de uma causa o faz perceber que as mortes em Cachoeira năo deveriam ser invisíveis, e percebia as mudanças que a mortandade dos "inocentes" da Santa Casa causava vasculhando os ânimos. A nota oficial, além de expor a gravidade da situaçâo, denuncia, por tabela, a condiçăo miserável e de esvaziamento dos direitos mais fundamentais, nos bairros da cidade, e deixa claro que são os pobres os mais atingidos. Essa foi uma situaçâo extrema que fez ressurgir outros problemas sociais e gerou os protestos de rua que aparecem na narrativa. Há um personagem, o chamado "cara-longe", que atua na narrativa como uma espécie de "boca do inferno"4 pois, por meio de suas informaçôes sobre a situaçấo na cidade, ele atua como provocador, escarnecedor e profanador:

O lixo se acumula na cidade. As carroças da Limpeza pública pararam. As moscas baixam. Os anjos sobem. E eu que me apelido de Herodes! Em vez de lixo, as carroças văo pegar curumim para o [cemitério] Santa Isabel. E entre as crianças condenadas está o filho de Deus? [...] os soldados de Herodes săo milhóes, se multiplicam em milhóes. O decreto será cumprido. Năo há mais Cremaçăo, as carroças da Limpeza se desconjuntaram. Nenhum inocente escapará. Outra dose, Aragăo. Desconfio que vem por aí um apocalipse (JURANDIR, 1984, p. 178).

A declaraçáo do personagem se mostra profícua em metáforas. Deus poderia representar o Poder e os soldados, a polícia - que iria reprimir os manifestantes e os inocentes - todos aqueles excluídos. O Herodes - referência bíblica clara ao perseguidor de Jesus Cristo que mandou matar várias crianças para descobrir o recém-nascido enviado de Deus -, seria a representaçâo do "Capital", como declarou, revoltado, um dos personagens, seu Lício: “- O Herodes dessa matança, o Herodes desse decreto, máes, pais, irmáos, o Herodes? É o Capital! O Capital!" (JURANDIR, 1984, p. 207), em

4 Referência ao apelido dado ao poeta baiano Gregório de Matos Guerra (1633-1696), devido aos seus poemas satíricos direcionados à sociedade política e religiosa da Era Colonial brasileira. 
uma crítica clara ao Poder e a como a mecanizaçăo do modo de vida e os ditames da economia estremeciam as questōes sociais.

A situaçấo se passa, mais especificamente, em um dos capítulos intitulado "O passeio, a mosca e os anjos". Nessa parte do romance, em que acontece a manifestaçáo popular, Dalcídio Jurandir opta por uma estrutura narratológica peculiar que se destaca na obra, pois há uma cena em que se ensaia uma estrutura teatral, por elencar vários personagens que năo têm nome, mas possui uma denominaçăo representante de determinado grupo que faz parte dos movimentos de reivindicaçăo, uma multidâo anônima.

É interessante notar que ao construir a parte da narrativa referente à cena do protesto dessa forma, o autor nos impulsiona a visualizar o movimento, a identificar e discernir as preocupaçóes e os anseios de cada grupo quando constrói imagens de modo bastante didático. Fazem parte do movimento: costureiras da fábrica Aliança; "uma voz"; a mulher grávida; "a primeira voz"; "a voz de outra mulher"; a Sociedade Beneficente dos Funileiros; a Federaçâo das Classes em Construçâo Civil; a Uniâo dos Caldeireiros de Ferro; os coveiros de Santa Izabel; "a voz do cabeludo", empunhando a bandeira. Nota-se a importância em ressaltar na expressăo de uma insatisfaçăo, a denominaçăo por "voz", no intuito de reforçar o fato de algo e alguém que precisa ser ouvido, a voz que conseguiu ultrapassar as barreiras da opressăo.

Na cena do protesto, além das vozes que trazem suas denúncias em gritos, destacadas em letra maiúscula para enfatizar o tom revoltoso, há ainda as faixas que identificam os grupos manifestantes, distinguidos no texto da narrativa também pelas letras maiúsculas. Observa-se, abaixo, um trecho do romance sobre o momento da manifestaçăo:

A doença, que os doutores náo davam nome, comia as criancinhas. Recuou noutro espanto, com o punho, roçando-lhe o nariz, de uma mulher, grávida, a voz rouca:

OS DOUTORES SÓ ESTĀO EM CONFERÊNCIA

SABER DA MOLÉSTIA SABEM? É FAZER DELES

E DOS DIPLOMAS DELES UMA FOGUEIRA SÓ

\section{Uma voz}

Fogueira, sim, mas no meio da rua. O forno da Cremaçăo apagou. 
Estou de sete meses. Vou ver meu filho saindo da minha barriga para a cova?

A primeira voz

Se o lixo acumula na cidade, assim também os títulos de doutor. Varrer primeiro o lixo das ciências e do governo. As podridóes da cidade começam dentro do Palácio e nas casas limpas envernizadas.

A mulher grávida

Como deixar meu filho aqui dentro mais meses até que passe a peste? Ah conservar meu filho mais tempo ou sempre dentro da barriga pra proteger ele do mundo e da morte!

A voz de outra mulher, o tamanco na măo, havia rompido a alça

Montóes de lixo na cidade. Menos nas ruas dos ricos, nos tapetes, dos salóes. Lá nos lindos berços náo tem anjo. Tem de se varrer o lixo que por fora é limpo. A mosca que mata as nossas crianças sai deles, choca dentro deles, dos limpos por dentro podres (JURANDIR, 1984, p. 202-203).

A questăo da voz também nos sugere um apontamento importante, se considerarmos que o momento é de tensâo e que toda revolta popular está sujeita à opressáo por meio da violência. Náo nominar os donos das vozes é uma forma de anonimato, esconder a identidade na luta contra a repressăo é uma estratégia de resistência. Assim sendo, observemos os gritos e as queixas dos manifestantes, as suas denúncias: o descaso dos médicos, o forno incinerador de lixo da Cremaçăo desativado levando a cidade ao acúmulo de dejetos e a infestaçấo das moscas. A "primeira voz" deixa claro que a culpa é do governo, "da podridâo da cidade que começa no Palácio e nas casas dos detentores do poder", ou seja, a podridăo está na mecânica grotesca do poder, como diria Foucault. No meio da multidăo, várias vozes, diferentes críticas ao governo:

Os coveiros querem ganhar mais e enterrar menos! Os eletricistas com as chaves dos transformadores podem apagar a luz da cidade? Só a diretoria de Londres pode resolver o caso dos salários da Pará Elétrica? [...] deu a peste nas crianças! O bairro do Marco está escurecendo de moscas. É um escurecer em cima das panelas, mesas, berços, das bocas do sono. Ninguém em casa pode abrir a boca (JURANDIR, 1984, p. 205).

Observa-se que as moscas obscureciam a cidade, como acinzentavam o futuro. E a alusâo às moscas como algo que impede de "abrir a boca", faz referência ao calar-se, ao emudecer-se, provavelmente por medo. Uma das cenas da Passagem nos demonstra 
que o protesto foi invadido pela cavalaria da polícia militar e alguns manifestantes estavam sendo perseguidos em suas próprias casas:

\begin{abstract}
Alfredo correu na d. Romana que muito calma historiava: um piquete de cavalaria assalta a Passagem, só faltou entrar cavalo adentro pela barraquinha "onde está seu filho" carregando livros e entre estes a Gramática, a Antologia, a Álgebra que a normalista atrás dos cavalarianos gritava que devolvessem. Do filho, o caldeireiro, d. Romana năo sabia (JURANDIR, 1984, p. 216).
\end{abstract}

A cena deixa claro o momento de repressăo policial e perseguiçấo política de um dos manifestantes que fazia parte da Uniăo dos Caldeireiros de Ferro, participante do protesto. É um momento característico do abuso de poder e estado de exceçăo. Invasáo de domicílios, perseguiçăo e até mesmo o confisco de livros, atitude muito comum de governos autoritários, por exemplo, na Ditadura Militar brasileira. No entanto, o contexto da obra de Dalcídio Jurandir năo se situa propriamente em um regime de exceçăo, mas podemos observar claramente elementos que caracterizam um estado de exceçăo. Complementamos essa observaçăo com o pensamento de Agamben:

A criaçáo voluntária de um estado de emergência permanente (ainda que, eventualmente, năo declarado no sentido técnico) tornou-se uma das práticas essenciais dos Estados contemporâneos, inclusive dos chamados democráticos. [...] o estado de exceçăo tende cada vez mais a se apresentar como paradigma de governo dominante na política contemporânea (AGAMBEN, 2003, p. 13).

O que Dalcídio Jurandir utiliza de forma estratégica na sua narrativa é a alusâo indefinida a um Governo, a um Estado. O que temos, portanto, é a representaçăo do Poder e a crítica do escritor às condiçōes humanas e sociais incoerentes com o Estado de Direito e mais próximas de um estado de exceçăo. Essas questôes aparecem em seu projeto estético literário como violaçăo e vida nua enrustidas em um estado permanente de emergência, "năo declarado em um sentido técnico", mas explícito na maneira como sua escrita constrói as deformidades da existência.

O estado de exceçâo é considerado uma medida de necessidade para situaçōes extremas. Giorgio Agamben (2012) nos elucida que o verdadeiro papel desempenhado pela exceçăo é suspender os direitos fundamentais. Nesse entremeio das decisóes soberanas nasce a vida nua, um elemento que se tornou essencial para que a exceçâo seja compreendida nos diversos âmbitos em que o problema da existência humana esteja atrelado às mazelas sociais. O desnudamento e o despojamento do corpo social congregam um vazio jurídico que se preenche de violaçóes constantes ao direito básico pela vida com dignidade, fraternidade, igualdade e liberdade.

O filósofo italiano traça um caminho importante para esclarecer o nascimento da exceçấo no seio dos estados de Direito. Ele avalia como esta evolui na esfera da soberania e de que forma a vida nua se configura no antro das consequências dessa açấo, tendo como objeto de análise os campos de concentraçăo nazistas a partir da obra de Primo Levi, um dos sobreviventes de Auschwitz. Desse modo, Agamben nos leva a refletir sobre o absurdo da existência e na vida nua, vida desqualificada pela suspensâo do ordenamento jurídico, que resulta do abuso de poder. 
Procura-se, nessa discussăo, estabelecer uma relaçăo entre a literatura, a filosofia e o direito, especificamente sobre a teoria da exceçăo, pois as narrativas literárias, e no caso de Dalcídio, uma narrativa que contradiz o discurso "oficial" sobre a Amazônia ficcional dos cronistas, permite-nos năo apenas entender a exceçăo no seu funcionamento unilateral enquanto medida, mas explorar as inúmeras possibilidades de ilustrá-la em suas consequências, além de evidenciá-la enquanto um agente que sempre se fez presente nas situaçóes de violência e barbárie. Essa complexa peculiaridade nos ajuda a observar a presença da exceçăo em suas mais diversas conjunturas.

Trata-se, portanto, - e esse é o fio condutor da discussâo - de apontar que o estado de exceçáo é uma medida-condiçáo produtora do que podemos sugerir como "espaços de exceçâo". Ou seja, independentemente das épocas, os lugares surgem, ressurgem, se constroem desordenadamente e se transmutam, mas serăo sempre terrenos profícuos para refletirmos na relaçăo entre cultura, História e barbárie. Nesse sentido, podemos considerar que o escritor Dalcídio Jurandir, ao assumir uma postura crítica sobre a vida amazônica, aguça seu olhar para os problemas existenciais diante da miséria assoladora que fere as bases fundamentais para uma vida digna.

Assim sendo, o escritor consegue perscrutar em suas obras características do estado de exceçâo que náo estăo diretamente ligadas ao contexto de guerra, mas que configuram outro tipo de barbárie: o absurdo de sobreviver ao esquecimento e à indiferença governamental provenientes de ideias mal concebidas acerca do dilema da utilidade e da inutilidade de cada cultura e de cada espaço, na contribuiçấo ao desenvolvimento econômico social, o que atualmente, na linguagem do Estado moderno, se camufla sob a égide de projetos democráticos.

Em seu discurso que emana da "periferia" latino-americana, Jurandir nos possibilita perceber o desencantamento do mundo e a desconstruçấo do ideal desse progresso criado como promessa de felicidade que náo favorece a todos. $\mathrm{O}$ autor demonstra um conhecimento profundo de seu local de enunciaçáo e afirma a autoridade de quem observa as implicaçôes resultantes da grande ilusăo plantada pela civilizaçâo do velho mundo, sobre os modos de vida que náo săo coerentes com as realidades descobertas.

Deste modo, Dalcídio Jurandir nos professa que a Amazônia năo interessa aos planos de "embelezamento" do projeto civilizacional da modernidade e, sendo empurrada cada vez mais para a margem do esquecimento, passa a vivenciar o desnudamento das necessidades essenciais do ser humano, construindo um campo de vidas matáveis que buscam pela sobrevivência. Os personagens de seus romances, portanto, vivem a experiência do corpo pela fome, pela miséria e pelas doenças. Assim sendo, o escritor desvenda e desconstrói a ideia criada pelos europeus de que a Amazônia é o El Dorado a ser explorado em sua riqueza e beleza e mostra a face destrutiva da modernidade ao descortinar que o verdadeiro inferno verde está na luta constante pela vida. 


\section{REFERÊNCIAS}

AGAMBEN, Giorgio. Estado de exceçāo. Săo Paulo: Boitempo, 2004.

Homo Sacer: O poder soberano e a vida nua. Belo Horizonte: Editora UFMG, 2010.

BENJAMIN, Walter. Documentos de cultura, documentos de barbárie: escritos escolhidos/ seleçăo e apresentaçăo Willi Bolle; traduçăo Celeste H. M. Ribeiro de Souza. Sâo Paulo: Cultrix, 1986.

BOSI, Alfredo. Literatura e resistência. São Paulo: Companhia das Letras, 2002.

JURANDIR, Dalcídio. Belém do Grāo-Pará. Belém: EDUFPA, 2004.

Passagem dos inocentes. Belém: Farangola, 1984.

CORNELSEN, Elcio. O "escritor operativo", o engajamento e a resistência. In: SARMENTOPANTOJA, Augusto; SARMENTO-PANTOJA, Tânia, UMBACH, Rosani (Org). Estudos de literatura de resistência. Săo Paulo: Pontes, 2014. 